\title{
Evaluation of the association between angiotensin converting enzyme insertion/deletion polymorphism and the risk of endometrial cancer in and characteristics of Polish women
}

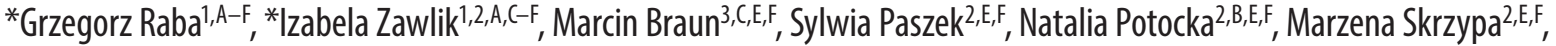 \\ Bogdan Obrzut ${ }^{4,5, B, E}$, Marek Kluza ${ }^{1, B, E}$, Katarzyna Kluza, ${ }^{1, B, E}$, Barbara Zych ${ }^{6, E, F}$, Magdalena Janowska ${ }^{7, B, E}$, Tomasz Kluz ${ }^{1, A, B, E}$ \\ ${ }^{1}$ Institute of Medical Sciences, College of Medical Sciences, University of Rzeszów, Poland \\ ${ }^{2}$ Laboratory of Molecular Biology, Centre for Innovative Research in Medical and Natural Sciences, College of Medical Sciences, University of Rzeszów, Poland \\ ${ }^{3}$ Department of Pathology, Chair of Oncology, Medical University of Lodz, Poland \\ ${ }^{4}$ College of Medical Sciences, University of Rzeszów, Poland \\ ${ }^{5}$ Department of Gynecology and Obstetrics, Provincial Clinical Hospital No. 2 in Rzeszów, Poland \\ ${ }^{6}$ Institute of Health Sciences, College of Medical Sciences, University of Rzeszów, Poland \\ ${ }^{7}$ Gynecology and Obstetrics Clinic, Frederic Chopin Clinical Provincial Hospital No. 1, Rzeszów, Poland \\ A - research concept and design; B - collection and/or assembly of data; $C$ - data analysis and interpretation; \\ $D$ - writing the article; $E$ - critical revision of the article; $F$ - final approval of the article
}

Address for correspondence

Izabela Zawlik

E-mail: izazawlik@yahoo.com

\section{Funding sources}

This study was supported by funding from the University of Rzeszów, College of Medical Sciences. The study was performed within the project "Centre for Innovative Research in Medical and Natural Sciences" carried out by the University of Rzeszów, co-financed within the Regional Operational Program for Podkarpackie Province for the period 2007-2013, contract No. UDA-RPPK.01.03.00-18-004/12-00.

Conflict of interest

None declared

* Grzegorz Raba and Izabela Zawlik contributed equally to this work.

Received on December 4, 2019

Reviewed on February 2, 2020

Accepted on March 10, 2020

Published online on May 22, 2020

\begin{abstract}
Background. Endometrial cancer is the most common malignant neoplasm of the female reproductive organs. A dysfunctional endometrial renin-angiotensin system (RAS) might contribute to the growth and spread of endometrial cancer. The RAS-related gene polymorphisms, including the polymorphism of insertion/ deletion (I/D) in the angiotensin-converting enzyme (ACE) gene, influence RAS activity.

Objectives. In the present study, we examined the association between the I/D polymorphism of the ACE gene and endometrial cancer risk in Polish women.

Material and methods. Genotype analysis of the ACEI/D polymorphism was carried out using polymerase chain reaction $(P C R)$ on 142 endometrial cancer type 1 patients and 68 cancer-free subjects. The results of the analyses were correlated with clinical data.

Results. The frequency of DD, DI and II ACE genotypes did not vary significantly between the experimental group and the control group (40 (28\%), 61 (43\%) and 41 (29\%) vs 18 (26\%), 31 (46\%), and 19 (28\%), respectively; $p=0.935)$. In addition, the incidence of the $D D, D I$ and II polymorphisms in the $A C E$ gene did not vary significantly between the experimental subgroups when stratified by cancer grade - G1, G2 and G3 endometrioid carcinoma - and the control group. Furthermore, the ACE polymorphism was not significantly associated with hypertension, diabetes or lymph node metastasis.
\end{abstract}

Conclusions. The ACEI/D gene polymorphism was not associated with endometrial cancer risk or the clinicopathological features in Polish women.

Key words: endometrial cancer, molecular biology, ACE gene polymorphism

DOI

10.17219/acem/118843

Copyright

Copyright by Author(s)

This is an article distributed under the terms of the

Creative Commons Attribution 3.0 Unported (CC BY 3.0)

(https://creativecommons.org/licenses/by/3.0/)

Cite as

Raba G, Zawlik I, Braun M, et al. Evaluation of the association between angiotensin converting enzyme insertion/deletion polymorphism and the risk of endometrial cancer in and characteristics of Polish women. Adv Clin Exp Med. 2020;29(5):581-585 doi:10.17219/acem/118843 


\section{Background}

Endometrial cancer is the most common malignant neoplasm of the female reproductive organs. The incidence of endometrial cancer is increasing worldwide. Potential risk factors for this disease include diabetes, obesity, hypertension, and relative hyperestrogenism. All of these conditions are associated with activation of the renin-angiotensin system (RAS). ${ }^{1,2}$ The RAS is an important aspect of the endocrine system that controls the fluidelectrolyte balance, aldosterone secretion and blood pressure regulation. Renin mediates the conversion of angiotensinogen (AGT) to angiotensin I (Ang I) and the protein des(Ang I)AGT. Both AGT and des(Ang I)AGT are noninhibitory serpins that can inhibit angiogenesis. Angiotensin II is the most active protein of the RAS, and is converted from Ang I by angiotensin-converting enzyme (ACE) through the removal of 2 amino acids. Angiotensin II acts through angiotensin II receptor type 1 (AGTR1) to induce cell proliferation and angiogenesis. ${ }^{3}$ As in all tissues, endometrial RAS is involved in the process of angiogenesis, neovascularization and cell proliferation. ${ }^{4}$ Thus, endometrial RAS affects tumor growth and spread.

The role of overexpression of the proangiogenic and proliferation-stimulating Ang II/AGTR1 combination has been demonstrated in the pathogenesis of several cancers, including breast, lung, prostate, and cervical cancer. ${ }^{5}$ Epidemiological data also supports the theory that the RAS plays a role in the formation of neoplasms. Pharmacological suppression of the RAS for the treatment of hypertension reduces the risk of cancer. The relative risk of reproductive tract cancer in women taking ACE inhibitors is 0.37 (0.12-0.87). ${ }^{6}$ Experimental studies in a mouse model demonstrated that the administration of AGTR1 antagonists significantly reduces tumor growth in the progression of endometrial cancer. ${ }^{7}$ Further, increased expression of Ang II, AGTR1, AGTR 2, vascular endothelial growth factor (VEGF), and the estrogen alpha receptor (NR3A1) has been observed in endometrial cancer tumors. ${ }^{8}$ In addition, a strong positive correlation has been observed between the expression of Ang II, AGTR 1 and AGTR 2, and advancing tumor grade and stage. ${ }^{8}$ Therefore, improper activation of the endometrial RAS may affect the formation and progression of endometrial cancer through the prorenin/ATP6AP2 and Ang II/AGTR1 pathways.

Excessive activation of the RAS may be observed more frequently in individuals with a single-nucleotide polymorphism (SNP) in the RAS system. The RAS-related gene polymorphisms influence RAS activity, including the polymorphism of insertion/deletion (I/D) in the $A C E$ gene. The $A C E$ gene encodes ACE type 1 and is located on the long arm of chromosome 17 (17q23), with a length of 21,000 base pairs (bp) comprised of 26 exons and 25 introns. Intron 16 of the $A C E$ gene contains a restriction fragment length polymorphism (RFLP) based on the presence (insertion I) or absence (deletion D) of a 287-base-pair non-sense DNA domain Alu repeat sequence (NCBI ref. SNP ID: rs1799752). There are 3 different $A C E$ gene genotypes: D/D and I/I homozygotes and I/D heterozygotes. The $\mathrm{D}$ allele is associated with higher $A C E$ activity in both the serum and tissue, in comparison with the I allele. ${ }^{9} A C E$ I/D polymorphisms are associated with a risk for several types of cancer, including breast, prostate and hepatocellular cancer. ${ }^{10-12}$ To the best of our knowledge, the only analysis of the $A C E$ gene I/D polymorphism in patients with endometrioid cancer was presented by Freitas-Silva et al., ${ }^{13}$ who reported that the $A C E$ polymorphism may be associated with the development of endometrial carcinoma and tumor onset in younger women. The clinical implications of the $A C E \mathrm{I} / \mathrm{D}$ polymorphism on endometrial cancer have yet to be established. The aim of our study was to examine the association between the $A C E \mathrm{I} / \mathrm{D}$ gene polymorphism and endometrial cancer risk and the clinicopathological features of the patients.

\section{Material and methods}

\section{Subjects}

The study included 210 Caucasian women: 142 with histopathologically confirmed endometrial cancer type 1 (study group) treated in the Clinical Departments of Gynecology and Obstetrics of Provincial Clinical Hospitals No. 1 and No. 2 in Rzeszów, Poland, and the Department of Gynecology and Obstetrics of the Provincial Hospital in Przemyśl, Poland. The control group comprised of 68 healthy women with no family history of cancer. The control group was recruited from among volunteers with negative results from prophylactic examinations in the Genetic Disorders Centre in Rzeszów. The study was carried out in 2017-2018. Peripheral blood samples were obtained from each individual and stored at $-80^{\circ} \mathrm{C}$ prior to analysis. The exclusion criteria included a current or prior diagnosis of cancer of any type. The study was approved by the Local Bioethics Committee (approval No. 90/B/2016). Data concerning age, body mass index (BMI), comorbidities (diabetes, hypertension, etc.), hormone replacement therapy, tobacco smoking, and alcohol consumption were collected using a questionnaire.

\section{DNA isolation and molecular analysis}

Genomic DNA was extracted from peripheral blood leukocytes using a rapid non-enzymatic method as reported by Lahiri et al. ${ }^{14}$ The genotyping of the ACE rs1799752 (I/D) polymorphism was carried out using polymerase chain reaction (PCR), estimated by the presence or absence of the $287 \mathrm{bp}$ sequence in intron 16 . We determined the occurrence of the I/D polymorphism based on the presence of a fragment of $193 \mathrm{bp}$ for the D allele and a fragment of $480 \mathrm{bp}$ for the I allele. The ACE polymorphisms were 
amplified using the PCR primers reported by Sanhueza et al. ${ }^{15}$ The optimal conditions were determined to be initial denaturation at $95^{\circ} \mathrm{C}$ for $10 \mathrm{~min}$ followed by 30 cycles of denaturation at $95^{\circ} \mathrm{C}$ for $60 \mathrm{~s}$, annealing at $64^{\circ} \mathrm{C}$ for $60 \mathrm{~s}$, and extension at $72^{\circ} \mathrm{C}$ for $60 \mathrm{~s}$, with a final extension at $72^{\circ} \mathrm{C}$ for $7 \mathrm{~min}$. The PCR amplifications were performed in a $\mathrm{T} 100^{\mathrm{TM}}$ Thermal Cycler (Bio-Rad, Hercules, USA). The amplification products were separated with electrophoresis through a $2 \%$ agarose gel (PB Genoplast Biochemicals, Rokocin, Poland) stained with Midori Green Stain (Nippon Genetics, Tokyo, Japan).

\section{Statistical analysis}

The categorical variables are presented as numbers with percentages in brackets. Differences between the categorical variables were evaluated using Pearson's $\chi^{2}$ test. Continuous variables are presented as medians and interquartile ranges (IQR) in brackets. The Shapiro-Wilk test was used to assess the distribution of continuous variables. Due to a non-normal distribution, continuous variables were compared using the Mann-Whitney U test for 2 groups, or the Kruskal-Wallis one-way analysis of variance (ANOVA) with additional post hoc comparisons for 3 or more groups. A correction for multiple testing was applied. The Hardy-Weinberg equilibrium of allele frequencies was tested for using an online calculator (http://www.oege.org/software/hwe-mr-calc.shtml). The STATISTICA v. 12.5 PL package (StatSoft, Inc., Tulsa, USA) was used for other analyses. P-values of less than 0.05 were considered statistically significant.

\section{Results}

Representative results of the $A C E \mathrm{I} / \mathrm{D}$ polymorphism are shown in Fig. 1.

The frequencies of genotypes for the $A C E \mathrm{I} / \mathrm{D}$ polymorphism among the study groups were consistent with

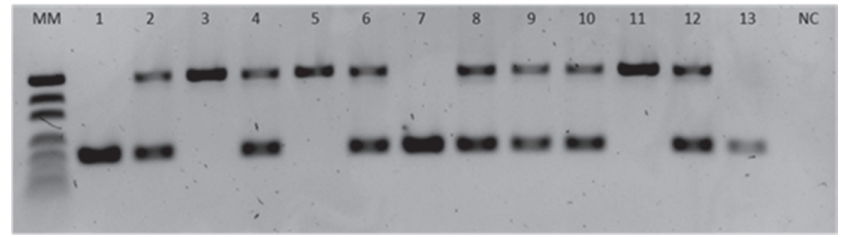

Fig. 1. Representative results of the insertion/deletion (I/D) polymorphism of a 287-bp fragment in intron 16 of the ACE gene

MM - DNA molecular mass markers (501, 404, 331, 242, 190, 147, and $110 \mathrm{bp}$ ); lanes 2, 4, 6, 8-10, and 12 I/D genotype (2 bands at $480 \mathrm{bp}$ and $193 \mathrm{bp}$ ); lanes 3, 5 and $11 \mathrm{l} / \mathrm{I}$ genotype (1 band at $480 \mathrm{bp})$; lanes 1, 7 and 13 D/D genotype (1 band at 193 bp); NC - negative control.

Table 1. ACE insertion/deletion (I/D) genotype distributions in patients with endometrial cancer and controls

\begin{tabular}{|c|c|c|c|}
$\begin{array}{c}\text { ACE I/D } \\
\text { genotype }\end{array}$ & $\begin{array}{c}\text { Experimental group } \\
\mathrm{n} \text { (\% of the group) }\end{array}$ & $\begin{array}{c}\text { Control group } \\
\mathrm{n} \text { (\% of the group) }\end{array}$ & p-value \\
\hline \multicolumn{3}{|c|}{ In the study: } \\
\hline DD & $40(28)$ & $18(27)$ & 0.935 \\
\hline ID & $61(43)$ & $31(46)$ & \\
\hline II & $41(29)$ & $19(28)$ & 1.000 \\
\hline DD & In perfect Hardy-Weinberg equilibrium: & \\
\hline ID & $35(25)$ & $16(24)$ & \\
\hline II & $71(50)$ & $34(50)$ & \\
\hline
\end{tabular}

The parameters fulfil the criterion for Hardy-Weinberg equilibrium ( $p>0.05)$, confirming that both the experimental and control groups in the present study are representative.

Hardy-Weinberg equilibrium (Table 1). The BMI was significantly different between the experimental group (30.49 (26.99-34.67)) and control group (26.29 (24.15-27.74)) $(\mathrm{p}<0.001)$. There were no differences in BMI between DD, DI and II $A C E$ polymorphisms in either the control or experimental group ( $\mathrm{p}=0.871$ and $\mathrm{p}=1.000$, respectively) (Table 2). The incidence of the DD, DI and II polymorphisms in the $A C E$ gene did not vary significantly among

Table 2. Characteristics of the groups by insertion/deletion (I/D) polymorphism of the ACE gene

\begin{tabular}{|c|c|c|c|c|c|}
\hline Factor & Group & $\begin{array}{l}\text { Homozygotes DD } \\
\text { median (IQR) }\end{array}$ & $\begin{array}{l}\text { Heterozygotes ID } \\
\text { median (IQR) }\end{array}$ & $\begin{array}{l}\text { Homozygotes II } \\
\text { median (IQR) }\end{array}$ & $p$-value \\
\hline \multirow{2}{*}{ BMI } & experimental & $\begin{array}{c}31.98 \\
(28.3-35.16)\end{array}$ & $\begin{array}{c}30.48 \\
(27.0-34.67)\end{array}$ & $\begin{array}{c}29.65 \\
(26.18-33.85)\end{array}$ & \multirow{2}{*}{$<0.001^{*}$} \\
\hline & control & $\begin{array}{c}26.55 \\
(25.05-27.13)\end{array}$ & $\begin{array}{c}26.45 \\
(24.12-28.0)\end{array}$ & $\begin{array}{c}25.41 \\
(24.12-27.28)\end{array}$ & \\
\hline \multirow{2}{*}{$\begin{array}{l}\text { Number } \\
\text { of births }\end{array}$} & experimental & $\begin{array}{c}2 \\
(1-3)\end{array}$ & $\begin{array}{c}2 \\
(1-3)\end{array}$ & $\begin{array}{c}2 \\
(2-3)\end{array}$ & \multirow{2}{*}{0.067} \\
\hline & control & $\begin{array}{c}3 \\
(1-4)\end{array}$ & $\begin{array}{c}2 \\
(2-3)\end{array}$ & $\begin{array}{c}2 \\
(1-3)\end{array}$ & \\
\hline \multirow{2}{*}{$\begin{array}{l}\text { Age at last } \\
\text { menstruation } \\
\text { [years] }\end{array}$} & experimental & $\begin{array}{c}50 \\
(48-55)\end{array}$ & $\begin{array}{c}52 \\
(46-55)\end{array}$ & $\begin{array}{c}50 \\
(49-53)\end{array}$ & \multirow{2}{*}{0.132} \\
\hline & control & $\begin{array}{c}49 \\
(47-53)\end{array}$ & $\begin{array}{c}53 \\
(49-54)\end{array}$ & $\begin{array}{c}51 \\
(48-55)\end{array}$ & \\
\hline
\end{tabular}

* In the post hoc analysis of the results, significant differences were only apparent between the cancer patients and the healthy controls, but BMI did not differ regarding ACE polymorphism. IQR - interquartile range; BMI - body mass index. 
Table 3. Comparison of the incidence of the ACE insertion/deletion (I/D) polymorphism between endometrioid cancer grades 1-3 and the control group

\begin{tabular}{|l|c|c|c|}
\hline \multicolumn{1}{|c|}{ Group } & Homozygotes DD & Heterozygotes ID & Homozygotes II \\
\hline Control group, n (\%) & $18(26)$ & $31(46)$ & $19(28)$ \\
\hline Experimental group, n (\%) & $40(28)$ & $61(43)$ & $41(29)$ \\
\hline G1, n (\%) & $16(23)$ & $28(43)$ & 0.935 \\
\hline G2, n (\%) & $16(30)$ & $26(48)$ & 0.754 \\
\hline G3, n (\%) & $8(47)$ & $5(29)$ & 0.764 \\
\hline
\end{tabular}

Table 4. Incidence of hypertension, diabetes, and metastases in the retroperitoneal lymph nodes in women with endometrioid carcinoma in relation to ACE insertion/deletion (I/D) polymorphism

\begin{tabular}{|l|c|c|c|c|}
\multicolumn{1}{|c|}{ Disease } & DD patients, $n(\%)$ & ID patients, $n(\%)$ & II patients, $n(\%)$ & $p$-value \\
\hline Hypertension $(n=29)$ & $8(20.0)$ & $13(21.7)$ & $8(20.0)$ & 0.971 \\
\hline Diabetes $(n=46)$ & $13(32.5)$ & $18(30.0)$ & $15(37.5)$ & 0.730 \\
\hline Lymph node metastasis $(n=8)$ & $3(9.7)$ & $4(7.7)$ & $1(3.13)$ & 0.570 \\
\hline
\end{tabular}

the experimental group when stratified by cancer grade - G1, G2 and G3 endometrioid carcinoma - and the control group (Table 3). In women with endometrial cancer, the DD, DI and II polymorphisms in the ACE gene did not significantly affect the concurrent incidence of hypertension $(\mathrm{p}=0.971)$ or diabetes $(\mathrm{p}=0.730)$. The polymorphism type also did not significantly affect the presence of lymph node metastases $(\mathrm{p}=0.570$; Table 4$)$.

\section{Discussion}

$A C E \mathrm{I} / \mathrm{D}$ polymorphisms are a risk factor for many types of cancer. ${ }^{10-12,16}$ Zhang et al. demonstrated that the $A C E$ $\mathrm{I} / \mathrm{D}$ polymorphism is associated with cancer risk in Caucasians in a meta-analysis of various adenocarcinomas, but they did not include studies of patients with endometrioid cancer. ${ }^{17}$ Some other studies, however, have reported no association between $A C E$ I/D polymorphism and cancer risk. ${ }^{18-21}$ In the present study, we found no significant correlations between $A C E$ I/D polymorphism and the incidence of endometrioid cancer, including cancer grades G1, G2 and G3. Moreover, we found no association between the $A C E$ gene polymorphism and hypertension, diabetes, or metastases to the retroperitoneal lymph nodes. To the best of our knowledge, the only analysis of $A C E$ gene I/D polymorphism in patients with endometrioid cancer was presented by Freitas-Silva et al., who suggested that $A C E$ polymorphism is associated with the development of endometrial carcinoma in women younger than 63 years of age. ${ }^{13}$ Their study was conducted on only 70 patients with endometrial cancer. Our results from 142 cases of endometrial cancer do not suggest any involvement of the $A C E \mathrm{I} / \mathrm{D}$ polymorphism in the development and progression of endometrioid cancer, regardless of age (menopausal status). Previous studies have established that the $A C E \mathrm{I} / \mathrm{D}$ polymorphism is functional. ${ }^{22,23}$
The lack of influence of the $A C E$ I/D polymorphism on the biology of endometrioid cancer in the population of Polish Caucasians reported here proves that $A C E \mathrm{I} / \mathrm{D}$ polymorphism alone cannot be a risk factor for endometrioid cancer.

One limitation of our study is the small sample size (a total of 210 women), which is important in research on polymorphisms. The Hardy-Weinberg equilibrium test, however, demonstrated that both the experimental group and the control group were representative. There are conflicting results describing the $A C E \mathrm{I} / \mathrm{D}$ polymorphism as a risk factor in prostate cancer: some studies reported that the $A C E \mathrm{I} / \mathrm{D}$ polymorphism is a risk factor, whereas other studies on other groups of patients found no such association. ${ }^{13,18}$ On the basis of these findings, other genetic and environmental factors may influence the development of endometrioid cancer and the clinicopathological features.

\section{Conclusions}

Our results revealed no association between the $A C E \mathrm{I} / \mathrm{D}$ gene polymorphism and endometrial cancer risk or the basic clinicopathological features among Polish Caucasian women.

\section{ORCID iDs}

Grzegorz Raba (D) https://orcid.org/0000-0002-9196-8548 Izabela Zawlik (1) https://orcid.org/0000-0001-7992-9100 Marcin Braun (D) https://orcid.org/0000-0003-3804-7042 Sylwia Paszek (D) https://orcid.org/0000-0002-7865-2661 Natalia Potocka (D) https://orcid.org/0000-0002-5505-3922 Marzena Skrzypa (D) https://orcid.org/0000-0001-7674-5912 Bogdan Obrzut (D) https://orcid.org/0000-0002-1293-1860 Marek Kluza (D) https://orcid.org/0000-0003-2827-6984 Katarzyna Kluza (D) https://orcid.org/0000-0003-0145-4701 Barbara Zych (D) https://orcid.org/0000-0001-8008-6630 Magdalena Janowska (D) https://orcid.org/0000-0003-3132-6436 Tomasz Kluz (1) https://orcid.org/0000-0002-4798-3986 


\section{References}

1. Bokhman JV. Two pathogenetic types of endometrial carcinoma. Gynecol Oncol. 1983;15(1):10-17.

2. Gorzelniak K, Janke J, Engeli S, Luft FC, Sharma AM. Upregulation of the AT(1) receptor human adipocytes by hydrocortisone.J Hypertens. 2002;20:S43-S43.

3. Rigat B, Hubert C, Alhencgelas F, Cambien F, Corvol P, Soubrier F. An insertion deletion polymorphism in the angiotensin I-converting enzyme gene accounting for half the variance of serum enzyme levels. J Clin Invest. 1990;86(4):1343-1346.

4. Li CB, Ansari R, Yu ZM, Shah D. Definitive molecular evidence of reninangiotensin system in human uterine decidual cells. Hypertension. 2000;36(2):159-164.

5. Deshayes F, Nahmias C. Angiotensin receptors: A new role in cancer? Trends Endocrinol Metabol. 2005;16(7):293-299.

6. Lever AF, Hole DJ, Gillis CR, et al. Do inhibitors of angiotensin-I-converting enzyme protect against risk of cancer? Lancet. 1998;352(9123): 179-184.

7. Koyama N, Nishida Y, Ishii T, Yoshida T, Furukawa Y, Narahara H. Telmisartan induces growth inhibition, DNA double-strand breaks and apoptosis in human endometrial cancer cells. PLoS One. 2014;9(3): e93050.

8. Piastowska-Ciesielska AW, Pluciennik E, Wojcik-Krowiranda K, Bienkiewicz A, Bednarek A, Ochedalski T. Analysis of the expression of angiotensin II type 1 receptor and VEGF in endometrial adenocarcinoma with different clinicopathological characteristics. Tumor Biol. 2012;33(3):767-774.

9. Teranishi J, Yamamoto R, Nagasawa Y, et al. ACE insertion/deletion polymorphism ( $r$ 1799752) modifies the renoprotective effect of renin-angiotensin system blockade in patients with IgA nephropathy. J Renin Angiotensin Aldosterone Syst. 2015;16(3):633-641.

10. Singh A, Srivastava N, Amit S, Prasad SN, Misra MP, Ateeq B. Association of AGTR1 (A1166C) and ACE (I/D) polymorphisms with breast cancer risk in North Indian population. Transl Oncol. 2018;11(2):233-242.

11. Medeiros R, Vasconcelos A, Costa S, et al. Linkage of angiotensin I-converting enzyme gene insertion/deletion polymorphism to the progression of human prostate cancer. J Pathol. 2004;202(3):330-335.

12. Yuan F, Zhang L-S, Li H-Y, Liao M, Lv M, Zhang C. Influence of angiotensin l-converting enzyme gene polymorphism on hepatocellular carcinoma risk in China. DNA Cell Biol. 2013;32(5):268-273.
13. Freitas-Silva M, Pereira D, Coelho C, Bicho M, Lopes C, Medeiros R. Angiotensin l-converting enzyme gene insertion/deletion polymorphism and endometrial human cancer in normotensive and hypertensive women. Cancer Genet Cytogenet. 2004;155(1):42-46.

14. Lahiri DK, Nurnberger Jl. A rapid nonenzymatic method for the preparation of HMW DNA from blood for RFLP studies. Nucleic Acids Res. 1991;19(19):5444.

15. Sanhueza JA, Zambrano T, Bahamondes-Avila C, Salazar LA. Association of anxiety-related polymorphisms with sports performance in Chilean long distance triathletes: A pilot study. J Sports Sci Med. 2016;15(4):554-561.

16. Vairaktaris E, Yapijakis C, Tsigris C, et al. Association of angiotensinconverting enzyme gene insertion/deletion polymorphism with increased risk for oral cancer. Acta Oncol. 2007;46(8):1097-1102.

17. Zhang K, Cheng D, Yi L, Shi H, Zhen G. Association between angiotensin I-converting enzyme gene polymorphism and susceptibility to cancer: A meta-analysis. Int J Clin Exp Pathol. 2014;7(9):6291-6300.

18. Wang Z-Y, Li H-Y, Jiang Z-P, Zhou T-B. Relationship between angiotensin-converting enzyme insertion/deletion gene polymorphism and prostate cancer susceptibility. J Cancer Res Ther. 2018;14(Suppl): S375-S380.

19. Li X-L, Zheng Z-J, Qu H-O. Lack of association of angiotensin-converting enzyme insertion/deletion polymorphism with breast cancer: An update meta-analysis based on 10405 subjects. J Renin Angiotensin Aldosterone Syst. 2015;16(4):1095-1100.

20. Wang N, Yang D, Ji B, Li J. Angiotensin-converting enzyme insertion/ deletion gene polymorphism and lung cancer risk: A meta-analysis. J Renin Angiotensin Aldosterone Syst. 2015;16(1):189-194.

21. Alves Correa-Noronha SA, Ribeiro de Noronha SM, Alecrim C, et al. Association of angiotensin-converting enzyme I gene I/D polymorphism with endometrial but not with ovarian cancer. Gynecol Endocrinol. 2012;28(11):889-891.

22. Xie Y, You C, Chen J. An updated meta-analysis on association between angiotensin l-converting enzyme gene insertion/deletion polymorphism and cancer risk. Tumor Biol. 2014;35(7):6567-6579.

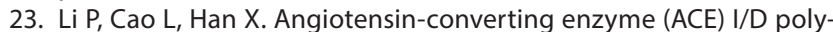
morphism is a risk factor of allergic rhinitis. Cell Moll Biol. 2017;63(8): 48-50. 